\begin{tabular}{|c|c|c|c|c|c|}
\hline JRL & Vol. 13 & No.2 & Hal. 152-165 & $\begin{array}{c}\text { Jakarta, } \\
\text { Desember 2020 }\end{array}$ & $\begin{array}{r}\text { p-ISSN : 2085.38616 } \\
\text { e-ISSN : 2580-0442 }\end{array}$ \\
\hline
\end{tabular}

\title{
ANALISIS TEKNO-EKONOMI PROSES PRETREATMENT AIR SUMUR DALAM DI WILAYAH TEMPAT PENGELOLAAN SAMPAH TERPADU BANTARGEBANG UNTUK PENGOLAHAN AIR UMPAN MEMBRAN REVERSE OSMOSIS
}

\author{
Muhammad Haqqiyuddin Robbani \\ Pusat Teknologi Lingkungan, Badan Pengkajian dan Penerapan Teknologi \\ Email: muhammad.haqqiyuddin@bppt.go.id
}

\begin{abstract}
Abstrak
Kinerja membran Reverse Osmosis (RO) sangat dipengaruhi salah satunya oleh karakteristik umpan yang digunakan. Namun belum ditemukan adanya data maupun publikasi terkait penyediaan air bersih dan air minum layak menggunakan teknologi membran RO dengan bahan baku air sumur dalam di wilayah Tempat Pengelolaan Sampah Terpadu (TPST) di Indonesia. Oleh karena itu tujuan dari penelitian ini adalah menganalisis kelayakan proses pretreatment air sumur dalam di wilayah TPST Bantargebang untuk air umpan membran RO dari aspek teknis dan ekonomis. Proses pretreatment yang dirancang berdasarkan hasil karakterisasi air sumur dalam dievaluasi kinerjanya dengan menggunakan software simulasi dan dihitung konsumsi energi spesifiknya. Evaluasi ekonomi dilakukan untuk mengetahui kelayakan desain proses pretreatment dari sisi pembiayaan. Setelah dilakukan simulasi, proses pretreatment menggunakan membran ultrafiltrasi dan resin kation asam kuat terbukti mampu menghilangkan kandungan zat terlarut yang tidak diinginkan hingga mencapai angka diatas $98 \%$. Konsumsi energi spesifik yang dibutuhkan proses pretreatment masih berada dalam rentang yang dapat diterima. Dengan kapasitas produksi minimal $300 \mathrm{~m}^{3} /$ hari biaya produksi yang dibutuhkan lebih rendah dari tarif air bersih Perusahaan Daerah Air Minum (PDAM) Bhagasasi. Sehingga, baik secara teknis maupun ekonomis, proses pretreatment air sumur dalam di wilayah TPST Bantargebang sangat layak untuk diimplementasikan kedepannya.
\end{abstract}

Kata Kunci: Tekno-Ekonomi, Pretreatment, Reverse Osmosis 


\title{
TECHNO-ECONOMIC ANALYSIS OF DEEP WELL WATER PRETREATMENT PROCESS IN BANTARGEBANG LANDFILL AREA FOR REVERSE OSMOSIS MEMBRANE FEED WATER TREATMENT
}

\begin{abstract}
The performance of the Reverse Osmosis (RO) membrane is greatly influenced, one of which is the characteristics of the feed used. However, no data or publication has been found related to the provision of clean water and drinking water using $R O$ membrane technology with raw material from deep well water in the landfill area in Indonesia. Therefore the aim of this research is to analyze the feasibility of the deep well water pretreatment process in the Bantargebang landfill area for RO membrane feed water from technical and economic aspects. The pretreatment process is designed based on the results of deep well water characterization, its performance is evaluated using simulation software and its specific energy consumption is calculated. Economic evaluation is carried out to determine the feasibility of the pretreatment process design in terms of budgeting. After the simulation, the pretreatment process using an ultrafiltration membrane and strong acid cation resin was proven to be able to remove unwanted zat terlarute content up to a figure above 98\%. The specific energy consumption required by the pretreatment process is still within an acceptable range. With a minimum production capacity of $300 \mathrm{~m}^{3} /$ day, the required production costs are lower than the clean water tariff of the Bhagasasi Regional Drinking Water Company. So, both technically and economically, the deep well water pretreatment process in the Bantargebang landfill area is very feasible to be implemented in the future.
\end{abstract}

Keywords: Techno-Economy, Pretreatment, Reverse Osmosis

Analisa Tekno -Ekonomi....JRL Vol. 13 No.2.Desember 2020 : 154 - 165 


\section{PENDAHULUAN}

Akses masyarakat umum untuk mendapatkan air bersih dan air minum yang layak masih dalam kondisi yang cukup mengkhawatirkan. Statistik Kesejahteraan Rakyat ${ }^{1}$ menunjukkan hanya $50 \%$ atau 17 provinsi yang berada diatas rata-rata nasional dalam hal ketersediaan akses masyarakat untuk mendapatkan air bersih. Sedangkan ketersediaan akses untuk air minum lebih rendah lagi (hanya $41 \%$ atau 14 provinsi yang berada diatas rata-rata nasional). Bila dilihat lebih lanjut, ketersediaan air bersih hanya meningkat $1 \%$ dari rata-rata tahun 2018, walaupun ketersediaan air minum layak meningkat hampir $100 \%$ dari rata-rata tahun 2018. Dari hasil statistik tersebut dapat dilihat bahwa ketimpangan akses air bersih dan air minum masih menjadi permasalahan serius di Indonesia, khususnya di daerah-daerah yang tidak terlayani oleh PDAM.

Statistik Kesejahteraan Rakyat tahun 2019 juga melaporkan bahwa sumber air minum didominasi oleh air minum dalam kemasan dalam satu dekade terakhir. Kondisi tersebut disebabkan oleh tercemarnya sumber air yang umumnya digunakan langsung oleh masyarakat seperti air sumur dalam maupun dangkal. Disisi lain teknologi membran RO telah berkembang pesat sebagai alternatif teknologi penyediaan air bersih dan air minum yang paling mumpuni. Keunggulan teknologi membran $\mathrm{RO}$, antara lain: rendahnya konsumsi energi, investasi lahan, dan biaya produksi; serta tingginya laju produksi menjadikan teknologi ini semakin marak digunakan ${ }^{2,3)}$.

Pengembangan dan penerapan teknologi membran $\mathrm{RO}$ juga terus dilakukan selama satu dekade terakhir oleh Pusat Teknologi
Lingkungan (PTL), yang merupakan unit kerja teknis di bawah Badan Pengkajian dan Penerapan Teknologi (BPPT), untuk menjawab kebutuhan masyarakat akan air bersih dan air minum ${ }^{4-8)}$. Sebelum teknologi membran RO dapat diterapkan, terlebih dahulu harus diketahui karakteristik dari air umpan yang akan digunakan. Hal ini diperlukan karena kinerja membran RO sangat dipengaruhi salah satunya oleh karakteristik umpan yang digunakan. Membran RO juga memiliki prasyarat maksimal khusus untuk beberapa parameter seperti Total Suspended Solid (TSS), Turbidity, dan Hardness ${ }^{9-11)}$. Nilai dari parameterparameter tersebut harus dipastikan memenuhi syarat agar tidak menghambat kinerja membran RO.

Sampai penelitian ini dilakukan, belum ditemukan adanya data maupun publikasi terkait penyediaan air bersih dan air minum layak menggunakan teknologi membran $\mathrm{RO}$ dengan bahan baku air sumur dalam di wilayah TPA/Tempat Pengolahan Sampah Terpadu di Indonesia. Menurut Widiasa dan Yoshi ${ }^{12)}$, di negara berkembang seperti Indonesia, memang umumnya jarang sekali ditemukan perekaman data yang baik dalam hal analisis tekno-ekonomi untuk penyediaan air bersih dan air minum di kawasan spesifik. Oleh karena itu tujuan dari penelitian ini adalah menganalisis kelayakan proses pretreatment air sumur dalam di wilayah TPST Bantargebang untuk air umpan membran RO dari aspek teknis dan ekonomis. TPST Bantargebang merupakan TPST terbesar yang ada di Indonesia dengan kapasitas sampah yang diolah mencapai 8000 ton per hari, sehingga diharapkan mampu menjadi contoh kasus yang tepat sebagai lokasi penelitian.

\section{METODE PENELITIAN}


Analisis ini mengambil lokasi di TPST Bantargebang, Bekasi, Jawa Barat sehingga karakteristik desain parameter proses dan ekonomi disesuaikan dengan kondisi dan peraturan di daerah setempat. Karakterisasi air sumur dalam dilakukan terlebih dahulu untuk nantinya dijadikan dasar dalam mendesain proses pretreatment. Kemudian desain proses dievaluasi kinerjanya dengan menggunakan software simulasi dan dihitung konsumsi energi spesifiknya. Pada tahap terakhir evaluasi ekonomi dilakukan untuk mengetahui kelayakan desain proses pretreatment dari sisi biaya produksi.

\subsection{Karakterisasi Air Sumur Dalam}

Karakterisasi air sumur dalam dilakukan dengan mengikuti standar SNI 06-6989. Karakteristik air sumur dalam di wilayah TPA Bantargebang yang dikaji sebatas pada parameterparameter yang mempengaruhi kinerja operasi pretreatment dan merupakan prasyarat air umpan membran RO seperti TSS, Turbidity, dan Hardness ${ }^{9}$.

\subsection{Desain Proses \\ dilakukan \\ Desain proses pretreatment mempertimbangkan karakteristik ai sumur dalam dan target prasyarat kualitas air umpan membran RO. Desain proses meliputi peralatan utama seperti membran ultrafiltrasi dan softener, maupun peralatan mikro seperti strainer.}

\subsection{Simulasi \\ Menggunakan WAVE}

Proses Pretreatment yang telah didesain dievaluasi kinerjanya dengan bantuan simulasi operasi menggunakan aplikasi WAVE. Parameter kinerja peralatan proses pretreatment yang dievaluasi adalah kemampuan pemisahan zat terlarut yang diwakili oleh nilai \%Rejeksi dengan mengikuti persamaan:

$$
\mathrm{R}=1-\frac{\mathrm{C}_{\text {downstream }}}{\mathrm{C}_{\text {upstream }}} \times 100 \%(1)
$$

Dimana $\mathrm{R}$ merupakan nilai Rejeksi dalam satuan persen (\%), $\mathrm{C}_{\text {downstream }}$ merupakan konsentrasi zat terlarut setelah proses pretreatment dalam satuan ppm, dan $\mathrm{C}_{\text {upstream }}$ merupakan konsentrasi zat terlarut sebelum proses pretreatment dalam satuan ppm.

\subsection{Menghitung Konsumsi Energi Spesifik}

Perhitungan konsumsi energi spesifik proses pretreatment mengikuti persamaan:

$$
E_{S}=\frac{P_{\text {Total }}}{Q_{\text {dowstream }}}
$$

Dimana $E_{s}$ merupakan nilai energi spesifik dalam satuan $\mathrm{kWh} / \mathrm{m}^{3}$, $P_{\text {Total }}$ merupakan tenaga total yang dikeluarkan dalam satuan kW, dan Qdowstream merupakan laju alir produk setelah proses pretreatment dalam satuan $\mathrm{m}^{3} / \mathrm{h}^{13}$ ).

\subsection{Evaluasi Ekonomi}

Evaluasi ekonomi dilakukan dengan menghitung biaya/ongkos produksi yang diperlukan tentunya dengan mempertimbangkan biaya modal dan biaya operasional. Kemudian biaya/ongkos produksi tersebut dibandingkan dengan tarif air PDAM Bhagasasi Bekasi. Adapun yang termasuk sebagai biaya modal antara lain pembelian peralatan utama, peralatan pendukung, biaya pengeboran sumur dalam, bangunan, dan biaya modal tidak langsung (asuransi, kontingensi). Sedangkan yang termasuk biaya operasional 
antara lain biaya listrik, pegawai, perawatan dan sparepart, bahan kimia, dan depresiasi alat.

\section{HASIL DAN PEMBAHASAN}

\subsection{Karakteristik Air Sumur Dalam}

Identifikasi karakteristik dari sebuah sumber bahan baku merupakan salah satu hal yang krusial dalam melakukan perancangan sistem. Hal tersebut juga berlaku dalam perancangan proses pengolahan air. Karakteristik sumber bahan baku sangat menentukan jenis peralatan apa yang akan dipilih untuk digunakan dalam sebuah sistem. Dalam penelitian ini karakteristik air sumur dalam diidentifikasi untuk mengetahui besaran zat terlarut yang terkandung guna dijadikan dasar dalam menentukan proses pretreatment yang tepat. Pengambilan sampel air sumur dalam dilakukan pada kedalaman $>60 \mathrm{~m}$ pada dua titik dengan jarak antara dua titik tersebut adalah sejauh $20 \mathrm{~m}$. Masing-masing titik diambil sebanyak tiga sampel air sumur dalam untuk dilakukan pengukuran. Hasil rata-rata dari seluruh sampel ditunjukkan oleh Tabel 1.

Tabel 1. Karakteristik Air Sumur Dalam di Wilayah TPST Bantargebang, Bekasi

\begin{tabular}{lrc}
\hline Parameter & Nilai & $\begin{array}{c}\text { Prasyarat } \\
\text { Umpan RO }\end{array}$ \\
\hline TSS (ppm) & 875,2 & $<10$ \\
$\begin{array}{l}\text { Turbidity } \\
\text { (NTU) }\end{array}$ & 13,1 & $<5$ \\
$\begin{array}{l}\text { Hardness } \\
\text { (ppm) }\end{array}$ & 463,5 & $<30$ \\
\hline
\end{tabular}

Sebagaimana terlihat jelas dalam Tabel 1 bahwa seluruh nilai parameter kualitas air sumur dalam belum memenuhi prasyarat air umpan membran $\mathrm{RO}^{9-11)}$. Nilai parameter TSS dan Turbidity yang mewakili kandungan padatan tidak terlarut dalam larutan mengindikasikan bahwa terdapat sejumlah besar partikel yang ada pada air sumur dalam yang dapat meningkatkan potensi terjadinya penyumbatan/fouling. Parameter lain yang memiliki peranan penting dalam menyebabkan terjadinya fouling dan scaling adalah Hardness atau kesadahan. Nilai Hardness yang tinggi mengindikasikan tingginya konsentrasi kation multivalen seperti ion Kalsium dan Magnesium yang terkandung dalam air sumur dalam. Nilai tersebut sangat berpotensi menyebabkan terjadinya fouling dan scaling pada peralatan membran $\mathrm{RO}$. Oleh karenanya, diperlukan suatu proses pretreatment untuk menurunkan nilai-nilai parameter tersebut agar dapat memenuhi prasyarat air umpan membran $\mathrm{RO}$.

\subsection{Desain Proses}

Untuk memenuhi prasyarat air umpan membran RO, tahapantahapan proses pretreatment dirancang sedemikian rupa sebagaimana yang disajikan pada Gambar 1. Peralatan pretreatment yang digunakan antara lain: (1) pompa sentrifugal; (2) strainer berukuran 150 mikrometer; (3) membran ultrafiltrasi; (4) tangki filtrat; (5) pompa sentrifugal; dan (6) tangki softener. Strainer berukuran 150 mikrometer digunakan untuk memisahkan komponen partikulat kasar yang terdispersi dalam aliran umpan air sumur dalam. Membran ultrafiltrasi difungsikan untuk menahan mikroorganisme dan makromolekul (dalam hal ini padatan tidak terlarut yang menyebabkan tingginya nilai TSS dan Turbidity) yang berada dalam aliran air sumur dalam. Sedangkan tangki softener 
digunakan untuk menyaring ion-ion multikovalen

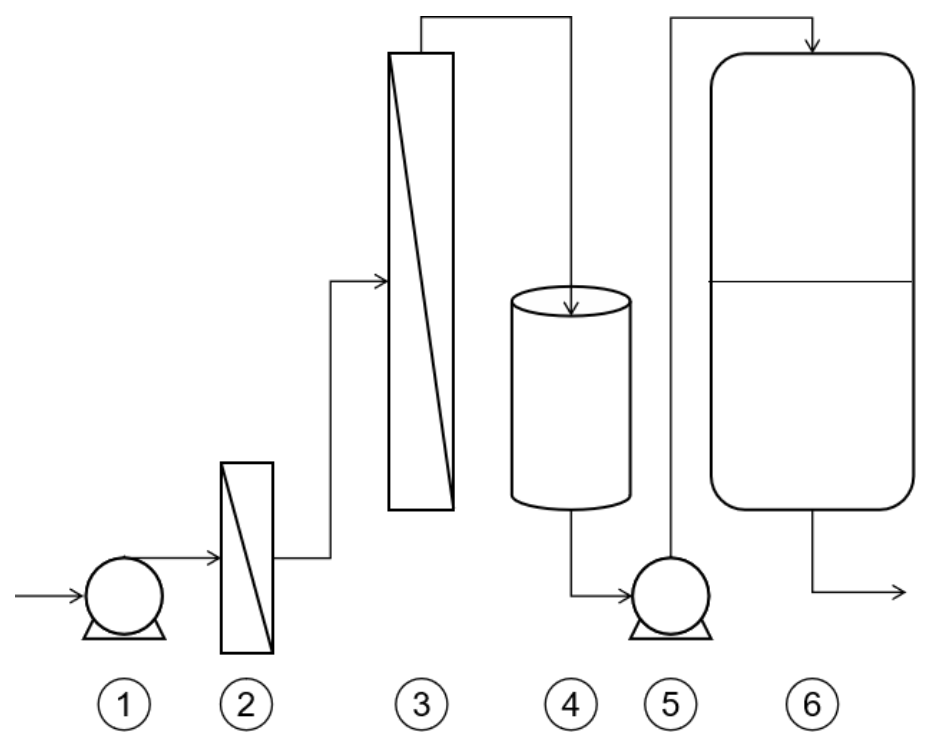

Gambar 1. Desain Proses Pretreatment

Kapasitas desain yang digunakan sebagai basis perhitungan adalah sebesar $12,5 \mathrm{~m}^{3} / \mathrm{jam}$ atau setara $300 \mathrm{~m}^{3} /$ hari produk air umpan membran $\mathrm{RO}$ yang dihasilkan. Penentuan kapasitas tersebut berdasarkan studi yang telah dilakukan oleh Widiasa dan Yoshi ${ }^{12)}$ terkait kapasitas minimal plant $\mathrm{RO}$, yakni sebesar $150 \mathrm{~m}^{3} /$ hari. Bila diasumsikan rasio recovery membran RO adalah $50 \%$, maka dibutuhkan aliran umpan setidaknya $300 \mathrm{~m}^{3} /$ hari. Rasio recovery membran ultrafiltrasi yang digunakan adalah sebesar $99,5 \%$. Tekanan operasi pemisahan yang digunakan adalah sebesar 3 bar. Jenis resin yang digunakan dalam tangki softener adalah kation asam kuat/strong acid cation (SAC). Rasio recovery yang digunakan adalah sebesar $89 \%$. Konfigurasi aliran tangki yang digunakan adalah jenis cocurrent. Run time atau siklus operasi berjalan yang digunakan adalah selama 8 jam.

\subsection{Kinerja Proses Pretreatment} Desain proses pretreatment yang telah dirancang kemudian disimulasikan dengan menggunakan aplikasi WAVE versi 1.72.724. Parameter-parameter proses yang telah ditentukan pada tahap sebelumnya diinputkan pada aplikasi termasuk hasil karakterisasi air sumur dalam. Proses pretreatment kemudian disimulasikan dan dikalkulasikan kinerja penyaringannya untuk mengetahui efektifitas dari desain yang telah dibuat. Kinerja proses pretreatment dievaluasi dengan melihat kemampuan pemisahan zat terlarut yang diwakili oleh nilai \%Rejeksi dari masing-masing zat terlarut yang belum memenuhi prasyarat air umpan membran RO. Rangkuman proses dan hasil simulasi dapat dilihat pada Gambar 2 dan Tabel 2. 


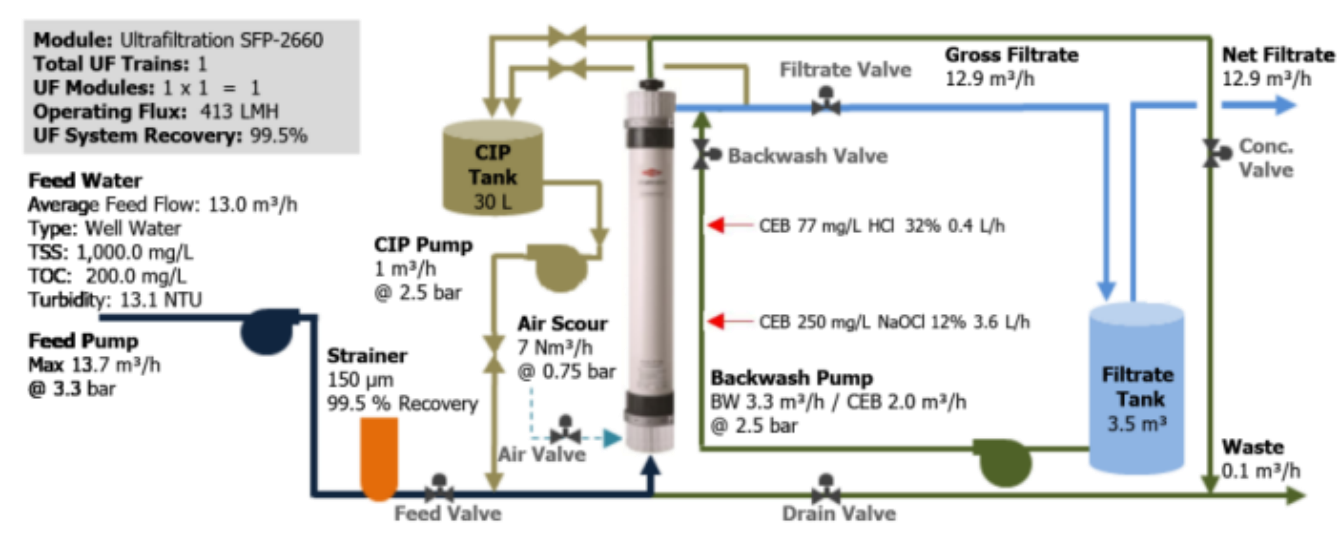

Gambar 2. Hasil Simulasi Proses

Seperti yang disajikan oleh Gambar 2, parameter-parameter lain yang belum ditentukan sebelumnya dapat dikalkulasikan oleh aplikasi. Begitu pula dengan peralatan pendukung dan instrumentasi seperi keran (valve), pompa backwash, serta tangki dan pompa pencucian juga secara otomatis disimulasikan oleh aplikasi. Sedangkan pada Tabel 2 dapat dilihat bahwa seluruh nilai \%rejeksi proses pretreatment hampir mencapai nilai sempurna dalam memisahkan zat terlarut pada air sumur dalam. Dapat dilihat pula bahwa kualitas air keluaran (output) dari proses pretreatment sudah memenuhi prasyarat air umpan membran RO baik pada parameter TSS, Turbidity, maupun Hardness.

Hasil-hasil yang ditampilkan pada Tabel 2 menunjukkan bahwa membran ultrafiltrasi dapat secara efektif menurunkan nilai TSS dan Turbidity. Hal ini disebabkan oleh prinsip pemisahan membran yang memiliki mekanisme pengayakan (sieving mechanism) berdasarkan perbedaan ukuran pori membran dengan partikel/zat terlarut yang ingin dipisahkan ${ }^{14)}$. Partikel yang mewakili nilai TSS dan Turbidity umumnya diwakili oleh jenis koloid-koloid halus ataupun makromolekul dengan ukuran diameter diatas $100 \mathrm{~nm}$. Sedangkan membran ultrafiltrasi memiliki ukuran pori direntang 2-100 $\mathrm{nm}$ yang memungkinkan partikel/zat terlarut yang menyebabkan nilai TSS dan Turbidity menjadi tinggi dapat tertahan.

\begin{tabular}{ccccc} 
Tabel 2. Rangkuman Hasil Simulasi Desain Proses Pretreatment \\
\cline { 2 - 4 } & $\begin{array}{l}\text { Parameter } \\
\text { (satuan) }\end{array}$ & Input & $\begin{array}{c}\text { Out- } \\
\text { put }\end{array}$ & $\begin{array}{c}\text { Prasyarat } \\
\text { umpan } \\
\text { RO }\end{array}$ \\
\hline $\begin{array}{l}\text { TSS } \\
\text { (ppm) }\end{array}$ & & $<0.1$ & $<10$ & 98,88 \\
$\begin{array}{l}\text { Turbidity } \\
\text { (NTU) }\end{array}$ & 13,1 & - & $<5$ & 100 \\
$\begin{array}{l}\text { Hardness } \\
\text { (ppm) }\end{array}$ & 463 & $<2$ & $<30$ & 99,57 \\
\hline
\end{tabular}

Nilai \%Rejeksi kesadahan atau Hardness yang mencapai 99,57\% menunjukkan bahwa resin softener juga secara efektif dapat menurunkan 
nilai kesadahan dalam air sumur dalam. Jenis resin kation asam kuat menjadi alasan dibalik tingginya nilai rejeksi tersebut. Resin asam kuat yang umumnya berisi gugus fungsional $\mathrm{SO}_{3} \mathrm{H}$ akan terionsasi menghasilkan ion $\left[\mathrm{SO}_{3}^{-}\right]$. Ion tersebut akan mengikat ion-ion multivalen seperti ion kalsium dan Magnesium penyebab tingginya nilai kesadahan air sumur dalam ${ }^{15}$.

Hasil simulasi pada penelitian ini sejalan dengan penelitian yang dilakukan oleh Castro-Muñoz ${ }^{16)}$ dan Vilayphone $\mathrm{dkk}^{17}$ ). Castro-Muñoz ${ }^{16)}$ melaporkan bahwa membran ultrafiltrasi secara efektif mampu menurunkan nilai TSS dan Turbidity pada permeat dari sebuah aliran limbah pemasakan jagung yang memiliki kandungan TSS dan Turbidity yang tinggi. Sedangkan Vilayphone dkk. ${ }^{17)}$, menyebutkan dalam hasil penelitiannya bahwa dibandingkan dengan weak acid cation (WAC), resin SAC lebih efektif dalam hal memitigasi kandungan ion Kalsium dan Magnesium dalam air. Oleh karenanya desain proses pretreatment dalam penelitian ini secara teknis dan kinerja sudah layak untuk diaplikasikan dalam menyiapkan air umpan membran $\mathrm{RO}$ dengan bahan baku air sumur dalam di wilayah TPST Bantargebang.

\subsection{Konsumsi Energi Spesifik \\ Setelah kinerja proses pretreatment telah dibuktikan} kelayakannya, maka perlu dilakukan evaluasi dari sisi yang tidak kalah penting yaitu konsumsi energi spesifik. Hal ini penting untuk dikaji mengingat konsumsi energi spesifik juga dapat mempengaruhi besarnya kebutuhan biaya operasional proses pretreatment yang nantinya akan berimbas pada tingginya biaya produksi air umpan membran RO. Konsumsi energi spesifik dihitung berdasarkan kebutuhan daya dari peralatan yang digunakan dalam proses pretreatment yang telah dirancang sebelumnya. Total konsumsi daya peralatan kemudian dibagi dengan laju alir produk setelah proses pretreatment untuk mendapatkan nilai konsumsi enegi spesifik. Kebutuhan daya dari masing-masing peralatan dan nilai konsumsi energi spesifik dari desain proses pretreatment yang telah dirancang dapat dilihat pada Tabel 3.

Tabel 3. Konsumsi Daya Peralatan dan Konsumsi Energi Spesifik Proses

\begin{tabular}{lrc}
\hline \multicolumn{1}{c}{ Item } & \multicolumn{1}{c}{ Nilai } & Satuan \\
\hline Qd & 12,5 & $\mathrm{~m}^{3} / \mathrm{h}$ \\
Pompa UF & 14,914 & $\mathrm{~kW}$ \\
Pompa SF & 14,914 & $\mathrm{~kW}$ \\
Pompa BW & 14,914 & $\mathrm{~kW}$ \\
Pompa CIP & 14,914 & $\mathrm{~kW}$ \\
Total P & 59,656 & $\mathrm{~kW}$ \\
Es & 4,77248 & $\mathrm{kWh} / \mathrm{m}^{3}$ \\
\hline
\end{tabular}

Dapat dilihat pada Tabel 3 bahwa setengah dari total daya yang diperlukan peralatan pada proses pretreatment berasal dari peralatan yang digunakan untuk pencucian membran. Artinya, konsumsi energi spesifik yang dibutuhkan untuk operasional harian hanya setengah dari konsumsi energi spesifik proses pretreatment secara keseluruhan. Hal tersebut menunjukkan betapa rendahnya kebutuhan daya untuk memproduksi tiap $\mathrm{m}^{3}$ air umpan membran RO. Rendahnya kebutuhan daya ini disebabkan oleh penggunaan kondisi operasi (tekanan) yang relatif 
rendah dalam memproses air sumur dalam (kisaran 3 bar), sehingga daya yang dibutuhkan oleh motor selaku penghasil driving force juga menjadi lebih rendah.

Hasil tersebut sesuai dengan temuan Widiasa dan Yoshi ${ }^{12)}$ yang menyatakan bahwa konsumsi energi spesifik untuk operasional pengolahan air menggunakan membran ultrafiltasi ada pada kisaran $2 \mathrm{kWh} / \mathrm{m}^{3}$. Pada studi tersebut membran ultrafiltasi digunakan untuk mengolah air umpan yang berasal dari keluaran Sewage Treatment Plant (STP). Karakteristik keluaran STP yang digunakan dalam studi tersebut mirip dengan air sumur dalam yang digunakan pada penelitian ini dari sisi parameter Turbidity dan TSS. Oleh karena itu konsumsi energi spesifik dari proses pretreatment yang telah dirancang pada penelitian ini masih berada dalam kisaran wajar bila dibandingkan dengan plant serupa.

\subsection{Evaluasi Ekonomi}

Dalam penelitian ini evaluasi ekonomi dihitung berdasarkan basis kapasitas produksi sebesar 300 $\mathrm{m}^{3}$ /hari. Perhitungan dilakukan menggunakan aplikasi WPS Office Spreadsheet versi 11.2.0.9747. Evaluasi ekonomi ini merujuk langsung kepada harga di lapangan sebagaimana yang ditinjukkan oleh Tabel 4 untuk memperoleh biaya produksi yang serealistis mungkin. Persamaan (3) - (12) dibutuhkan untuk menentukan biaya produksi ${ }^{12)}$. Hargaharga yang tertera sebagian dikutip dari Widiasa dan Yoshi ${ }^{12)}$ dengan penyetaraan menggunakan Plant Cost Index ${ }^{18)}$.

*TDL untuk Industri >6600VA ${ }^{19)}$

Tabel 4. Nilai Parameter Ekonomi

\begin{tabular}{|c|c|c|c|}
\hline Parameter & & Nilai & Satuan \\
\hline Plant Capacity & $\mathrm{m}$ & 300 & $\mathrm{~m}^{3} /$ day \\
\hline Energi Spesifik & w & 4,77 & $\mathrm{kWh} / \mathrm{m}^{3}$ \\
\hline Life Time & $\mathrm{n}$ & 10 & year \\
\hline Availability & f & 90 & $\%$ \\
\hline Interest & $\mathrm{i}$ & 13 & $\%$ \\
\hline Listrik* & c & 1.352 & $\mathrm{Rp} / \mathrm{kWh}$ \\
\hline Pegawai** & $y$ & $4.589 .708,9$ & Rp/p/bulan \\
\hline j. Pegawai & $\mathrm{p}$ & 3 & orang \\
\hline Membran & $x$ & $10.354 .493,2$ & Rp/unit \\
\hline j. membran & $\mathrm{b}$ & 18 & unit \\
\hline Depresiasi & d & $5.529 .277,25$ & $\mathrm{Rp} / \mathrm{m}^{3} /$ day \\
\hline Chemical & $\mathrm{k}$ & $1.075,14$ & $\mathrm{Rp} / \mathrm{m}^{3}$ \\
\hline Pajak Air ${ }^{* * *}$ & $\mathrm{t}$ & 600 & Rp. $\mathrm{m}^{3}$ \\
\hline
\end{tabular}

**UMK Kota Bekasi 2020

${ }^{\star * *}$ Pajak Air Daerah Bekasi ${ }^{20-21)}$

$\begin{array}{ll}A_{\text {air }} & =t . m . f .365 \\ a & =\frac{i(1+i)^{n}}{(1+i)^{n}-1} \\ A_{\text {depresiasi }} & =\text { a.d } \\ A_{\text {listrik }} & =\text { c.w.m.f.365 (6) } \\ A_{\text {kimia }} & =k . m . f .365\end{array}$




$$
\begin{array}{ll}
A_{\text {tenaga }} & =y \cdot p \cdot 13 \\
A_{\text {membran }} & =30 \% \cdot x \cdot b \\
A_{\text {perawatan }} & =2 \% \cdot d \\
A_{\text {Total }} & =A_{\text {air }}+A_{\text {depresiasi }}+ \\
& A_{\text {listrik }}+A_{\text {kimia }}+ \\
& A_{\text {tenaga }}+A_{\text {membran }}+ \\
& A_{\text {perawatan }} \\
& =\frac{A_{\text {Total }}}{m \cdot f \cdot 365}
\end{array}
$$

Dengan mengkalkulasikan nilainilai parameter ekonomi yang tertera pada Tabel 2 dengan menggunakan persamaan (3) - (12), didapatkan hasil besaran biaya produksi yakni sebesar Rp 10.533,- $/ \mathrm{m}^{3}$. Besaran tersebut tergolong rendah bila dibandingkan dengan tarif PDAM Bhagasasi Bekasi untuk industri besar ${ }^{22)}$ yaitu sebesar Rp 16.984,- $/ \mathrm{m}^{3}$ untuk kapasitas $>10 \mathrm{~m}^{3}$. Biaya tersebut bahkan belum termasuk biaya penyambungan jaringan PDAM. Sehingga dapat dilihat bahwa secara ekonomis, produksi air umpan membran RO dengan bahan baku air sumur dalam di wilayah TPST Bantargebang masih sangat layak untuk direalisasikan.

\section{KESIMPULAN DAN SARAN}

Proses pretreatment air sumur dalam di wilayah TPST untuk air umpan membran $\mathrm{RO}$ telah dianalisis kelayakannya, baik dari sisi teknis maupun ekonomis. Ditemukan bahwa kandungan TSS, Turbidity, dan Hardness pada air sumur dalam cukup tinggi, sehingga perlu dilakukan proses pretreatment. Setelah dilakukan simulasi, proses pretreatment menggunakan membran ultrafiltrasi dan resin SAC terbukti mampu menghilangkan kandungan zat terlarut yang tidak diinginkan hingga mencapai angka diatas $98 \%$. Konsumsi energi spesifik yang dibutuhkan proses pretreatment masih berada dalam rentang yang dapat diterima. Dengan kapasitas produksi minimal $300 \mathrm{~m}^{3} /$ hari biaya produksi yang dibutuhkan lebih rendah dari tarif air bersih PDAM Bhagasasi. Sehingga, baik secara teknis maupun ekonomis, proses pretreatment air sumur dalam di wilayah TPST Bantargebang sangat layak untuk diimplementasikan kedepannya. Evaluasi sensitivitas biaya produksi terhadap tarif pajak, listrik, dan inflasi perlu dilakukan di masa mendatang guna menguatkan akurasi hasil analisis ekonomi proses pretreatment yang dilakukan dalam penelitian ini.

\section{DAFTAR PUSTAKA}

Badan Pusat Statistik. 2019. Statistik Kesejahteraan Rakyat 2019. Jakarta: Badan Pusat Statistik.

Said, N.I. 2009. Uji Kinerja Pengolahan Air Siap Minum dengan Proses Biofiltrasi, Ultrafiltrasi dan Reverse Osmosis (RO) dengan Air Baku Air Sungai. Jurnai Air Indonesia. Jakarta.

Ariyanti, D. and Widiasa, I.N. 2011. Aplikasi Teknologi Reverse Osmosis Untuk Pemurnian Air Skala Rumah Tangga. Teknik, 
32(3), pp.193-197.

Herlambang, A., 2011. Teknologi penyediaan air minum untuk keadaan tanggap darurat. Jurnal Air Indonesia, 6(1).

Setiadi, I. and Kristyawan, I.P.A., 2018. Teknologi Pengolahan Air Gambut Asin Menjadi Air Siap Minum di Kelurahan Tanjung Tengah, Penajam, Kalimantan Timur. Jurnal Air Indonesia, $8(2)$.

Setiadi, I., 2019. Pengaman Laju Air Umpan Untuk Arsinum Kapasitas 5M3/Hari Menggunakan Pressure Switch dan Selenoid Valve. Jurnal Rekayasa Lingkungan, 11(2).

Robbani, M.H. and Setiadi, I., 2019. OPTIMALISASI KINERJA PERANGKAT PENINGKAT $\mathrm{pH}$ BERBASIS RESIN MAGNESIUM OKSIDA UNTUK PRODUKSI AIR SIAP MINUM. Jurnal Rekayasa Lingkungan, 12(2).

Yudo, S. and Sitomurni, A.I., 2019. Implementasi

Teknologi

Pengolahan Air Siap Minum dan Pengembangan Usaha Galon Air Siap Minum Studi Kasus: Penerapan Teknologi Pengolahan Air Siap Minum Di SMK Al-Kahfi, Sumbawa. Jurnal Rekayasa Lingkungan, 11(2).

Auqasafemine. 2020. Standard Specifications of Brackish Water Reverse Osmosis. http://www.aquasafemine.com/ brackish-water-reverseosmosis/. diakses 11 November 2020

CSM Saehan. 2006. Technical Manual Reverse Osmosis Membrane. Available on: http://www.csmfilter.com/search file/file/tech_manual.pdf

Dupont and Water Solutions, 2020. FILMTEC $^{\mathrm{TM}}$ Reverse Osmosis Membranes Technical Manual Version 4. Available on: https://www.dupont.com/conten t/dam/dupont/amer/us/en/water-

zat

terlarutions/public/documents/e n/45-D01504-en.pdf.

Widiasa, I.N. and Yoshi, L.A., 2016. Techno Economy Analysis a Small Scale Reverse Osmosis System for Brackish Water Desalination. International Journal of Science and Engineering, 10(2), pp.51-57.

Sharif, A.O., Merdaw, A.A., Aryafar, M. and Nicoll, P., 2014. Theoretical and experimental investigations of the potential of osmotic energy for power production. Membranes, 4(3), pp.447-468.

Susanto, H., 2011. Teknologi Membran. Semarang: Badan Penerbit Universitas Diponegoro.

Hashemi, F., Hashemi, H., Shahbazi, M., Dehghani, M., Hoseini, M. and Shafeie, A., 2020. Reclamation of real oil refinery effluent as makeup water in cooling towers using ultrafiltration, ion exchange and multioxidant disinfectant. Water Resources and Industry, 23, p.100123.

Castro-Muñoz, R., 2020. Retention profile on the physicochemical properties of maize cooking byproduct using a tight ultrafiltration membrane. Chemical Engineering Communications, 207(7), pp.887-895.

Vilayphone, V., Outram, J.G., Collins, F., Millar, G.J. and Altaee, A., 2020. Process design of coal seam gas associated water treatment plants to facilitate beneficial reuse. Journal of Environmental Chemical Engineering, 8(5), p.104255.

Lozowski, D. 2020. The Chemical Engineering Plant Cost Index. https://www.chemengonline.co $\mathrm{m} / \mathrm{pci}$-home . diakses 11 November 2020 
Peraturan Menteri Energi dan Sumber

Daya Mineral Republik

Indonesia Nomor 28 Tahun

2016 tentang Tarif Listrik yang

Disediakan oleh PT Perusahaan

Listrik Negara (Persero).

Peraturan Daerah Kota Bekasi Nomor

04 Tahun 2011 tentang Pajak

Air Tanah

Peraturan Walikota Bekasi Nomor 38

Tahun 2011 tentang Tata Cara

Perhitungan Harga Dasar Air

sebagai Dasar Penetapan Nilai

Perolehan Air Tanah

Peraturan Bersama Bupati Bekasi dan

Walikota Bekasi Nomor 45

Tahun 2014 tentang Tarif Dasar

Air Minum dan Biaya

Langganan Pada Perusahaan

Daerah Air Minum Tirta

Bhagasasi Bekasi 